skal gjennomgå allogen stamcelletransplantasjon. Det er anbefalt å starte kelerende behandling når s-ferritinnivået er $>1500 \mu \mathrm{g} / \mathrm{l}$ eller etter omtrent 25 enheter med SAG-erytrocytter. Målverdien for behandling av forhøyet jernlager er s-ferritin $<1000 \mu \mathrm{g} / 1$ (2).

Vi mener at det er sannsynlig at den jernkelerende behandlingen er bidragende til at denne pasientens kliniske tilstand er blitt mye bedre. Det er imidlertid ikke publisert noen kontrollerte randomiserte fase 3-studier om kelerende behandling hos pasienter med myelodysplastisk syndrom. Det som finnes av slik dokumentasjon, er gjort hos talassemipasienter. Retrospektive studier og mindre prospektive fase 2 -studier hos pasienter med myelodysplastisk syndrom tyder imidlertid på gunstige effekter, som nevnt over.

Vår pasient illustrerer det potensielle problemet i å la være å kelere pasienter med myelodysplastisk syndrom med god prognose og stort transfusjonsbehov. Det pågår for tiden en randomisert multinasjonal studie for bedre å dokumentere effekten.

Pasienten har gitt samtykke til at artikkelen blir publisert.

\section{Kiarash Tazmini (f. 1976)}

er lege og stipendiat ved Diakonhjemmet Sykehus og ved Institutt for eksperimentell medisinsk forskning (IEMF), Oslo universitetssykehus, Ullevål.

Forfatter har fylt ut ICMJE-skjemaet og oppgir ingen interessekonflikter.

\section{Heidi Nygaard Bakken (f. 1980)}

er lege ved Oslo universitetssykehus, Ullevål. Forfatter har fylt ut ICMJE-skjemaet og oppgir følgende interessekonflikter: Har mottatt reisetilskudd fra GSK og AstraZeneca.

\section{Fredrik Hellem Schjesvold (f. 1975)}

er spesialist $\mathrm{i}$ indremedisin og overlege ved Medisinsk avdeling, Bærum sykehus.

Forfatter har fylt ut ICMJE-skjemaet og oppgir ingen interessekonflikter.

\section{Litteratur}

1. Greenberg P, Cox C, LeBeau MM et al. International scoring system for evaluating prognosis in myelodysplastic syndromes. Blood 1997; 89 2079-88.

2. Guidelines for the diagnosis and treatment of myelodysplastic syndromes and chronic myelomono- cytic leukemia. Nordic MDS group, issue 6, 5th update, december 2011. www.nmds.org (25.5.2012).

3. Pullarkat $\mathrm{V}$. Objectives of iron chelation therapy in myelodysplastic syndromes: more than meets the eye? Blood 2009; 114: 5251-5.

4. Fleming RE, Ponka P. Iron overload in human disease. N Engl J Med 2012; 366: 348-59.

5. Brittenham GM. Iron-chelating therapy for transfusional iron overload. N Engl J Med 2011; 364 $146-56$.

6. Leitch HA. Controversies surrounding iron chelation therapy for MDS. Blood Rev 2011; 25: 17-31.

7. Tolley K, Oliver N, Miranda E et al. Cost effectiveness of deferasirox compared to desferrioxamine in the treatment of iron overload in lower-risk. transfusion-dependent myelodysplastic syndrome patients. J Media Econ 2010: 13: 559-70.

8. Badawi MA, Vickars LM, Chase JM et al. Red blood cell transfusion independence following the initiation of iron chelation therapy in myelodysplastic syndrome. Adv Hematol 2010; 2010: 164045.

9. Yeh SP, Yang YS, Yao CY et al. Iron chelation therapy for patients with myelodysplastic syndrome. Hemoglobin 2009; 33: 339-45.

Mottatt 19.5. 2011, første revisjon innsendt 9.1. 2012, godkjent 25.5. 2012. Medisinsk redaktør Mette Sagsveen.

\title{
Jernkelering ved myelodysplastisk syndrom
}

Engelsk oversettelse på www.tidsskriftet.no

Myelodysplastisk syndrom er en samlebetegnelse for flere klonale, premaligne eller maligne beinmargssykdommer med modningshemmet hematopoese og cytopeni i perifert blod (1). Medianoverlevelsen avhenger av hvilken undergruppe pasienten tilhører og av risikoskår. Dødsårsaken er ofte utvikling av akutt leukemi eller direkte komplikasjoner til beinmargssvikt (1).

Multitransfusjon og modningshemmet erytropoese kan føre til jernakkumulering (2). Kiarash Tazmini og medarbeidere gir en lærerik beskrivelse av alvorlige kliniske manifestasjoner av dette. De omtaler en pasient med en prognostisk relativt gunstig type myelodysplastisk syndrom, refraktær anemi med ringsideroblaster. Hun hadde likevel stort transfusjonsbehov, med massiv jernakkumulering, og hun utviklet alvorlig multiorgansvikt. Kraftig jernkelerende behandling hadde gunstig og muligens livreddende effekt.

Ved myelodysplastisk syndrom med transfusjonsbehov kan man vurdere å redusere jerndepotene profylaktisk $(2,3)$. To jernkelerende preparater er registrert i Norge for denne indikasjonen. Desferoksamin er billigst, men må gis parenteralt ved hjelp av infusjonspumpe. Deferasiroks tas peroralt, men er svært kostbart og kan gi bivirkninger fra nyrer og fra syns- og hørselsorganer.

Det er god dokumentasjon for at medianoverlevelsen er kortere ved stor enn ved liten jernakkumulering (2). Ulik overlevelse avspeiler imidlertid ikke nødvendigvis skadelig effekt av jernakkumuleringen eller prognostisk gevinst ved profylaktisk intervensjon. Forskjellen i prognose kan tenkes å bero på at «de sykeste er sykest»: Pasienter i ugunstig prognosegruppe har gjerne størst transfusjonsbehov og dermed mest jernakkumulering. Moderat jernoverskudd er relativt ufarlig. Ved primær hemokromatose er kardiomyopati og levercirrhose uvanlig ved et ferritinnivå $<4000 \mu \mathrm{g} / 1$ og forekommer nesten aldri ved et ferritinnivå $<1000 \mu \mathrm{g} / \mathrm{l}$ (4). Ved myelodysplastisk syndrom kan det dessuten være usikkert om pasienten vil leve lenge nok til at jerndeponeringen får klinisk betydning.

Hensiktsmessig bruk av profylaktisk jern- kelering ved myelodysplastisk syndrom forutsetter derfor kliniske studier, der eventuell livsforlengelse, symptombedring, bivirkninger, kostnader og livskvalitet bør være endepunkter. Retrospektive data tyder på gunstig effekt hos grupper med rimelig lang medianoverlevelse og stort transfusjonsbehov $(2,5$, $6)$. En retrospektiv multisenterstudie viste medianoverlevelse på 124 måneder i en gruppe som hadde fått jernkelering, mot 53 måneder der slik behandling ikke var gitt (6). Siden studien ikke var prospektiv eller randomisert, kan man ikke vite om de to gruppene var sammenliknbare. Funnene er derfor usikre.

I det nordiske handlingsprogrammet for myelodysplastisk syndrom anbefales profylaktisk jernkelering til gruppen med et ferritinnivå $>1500 \mu \mathrm{g} / \mathrm{l} \mathrm{og}$ en forventet medianoverlevelse på over to år, men det presiseres at dokumentasjonen er utilstrekkelig (3). Mange vil nok mene at denne anbefalingen er for liberal så lenge kunnskapsgrunnlaget 
ikke er sterkere. Randomiserte, prospektive studier vil forhåpentlig vise riktig vei.

\section{Sigbjørn Berentsen}

sigbjorn.berentsen@haugnett.no

Medisinsk klinikk

Haugesund sjukehus

Sigbjørn Berentsen (f. 1948) er dr.med. og spesialist i indremedisin. Han er seksjonsoverlege ved Medisinsk klinikk, Haugesund sjukehus, fagansvarlig for blodsykdommer i Helse Fonna og førsteamanuensis ved Universitetet i Bergen. Forfatter har fylt ut ICMJE-skjemaet og oppgir ingen interessekonflikter.

\section{Litteratur}

1. Brunning RD, Orazi A, Germing $U$ et al. Myelodysplastic syndromes. I: Swerdlow SH, Campo E, Harris NL et al, red. WHO classification of tumours of haematopoietic and lymphoid tissues. 2. utg. Lyon: International Agency for Research on Cancer, 2008: 88-93

2. Leitch HA. Controversies surrounding iron chelation therapy for MDS. Blood Rev 2011: 25: 17-31.

3. Nordic MDS group. Guidelines for the diagnosis and treatment of myelodysplastic syndromes and chronic myelomonocytic leukemia. 2011. www-nmds-org/Nordic-Care-Programme (21.6.2012).

4. Åsberg A, Hveem K, Thorstensen K et al. Screening for hemochromatosis: high prevalence and low morbidity in an unselected population of 65,238 persons. Scand J Gastroenterol 2001; 36: 1108-15.

5. Neukirchen J, Fox F, Kündgen A et al. Improved survival in MDS patients receiving iron chelation therapy - a matched pair analysis of 188 patients from the Düsseldorf MDS registry. Leuk Res 2012 36: 1067-70.

6. Rose C, Brechignac S, Vassilief D et al. Does iron chelation therapy improve survival in regularly transfused lower risk MDS patients? A multicenter study by the GFM (Groupe Francophone des Myélodysplasies). Leuk Res 2010; 34: 864-70.

Mottatt 21.6. 2012, første revisjon innsendt 30.6 2012, godkjent 30.6. 2012. Medisinsk redaktør Kristin Viste. 